\title{
Gen Z's Reception of Covid-19 Information on Digital Media
}

\author{
${ }^{1}$ Ratri R. Kusumalestari, ${ }^{2}$ Arba'iyah Satriani, ${ }^{3}$ Andalusia N. Permatasari, ${ }^{4}$ Millenia Anjani, \\ ${ }^{5}$ Nova N. Nadifah \\ 1,2,3,4,5 Fakultas Ilmu Komunikasi, Universitas Islam Bandung, Jalan Tamansari No.1 Bandung, Indonesia. \\ E-mail: ${ }^{1}$ ratri@unisba.ac.id, ${ }^{2}$ arbaiyahsatriani@unisba.ac.id, ${ }^{3}$ andalusia@unisba.ac.id, \\ ${ }^{4}$ milleniaanjali@gmail.com, ${ }^{5}$ nadifahnova@gmail.com,
}

\begin{abstract}
As a generation that was born and grew up with digital technology that is developing very quickly, Gen $Z$ has different characteristics from other generations. Gen $Z$ 's acceptance of information related to Covid-19 is one of the important things to assess regarding their potential role and quantity. This study aims to explore Gen-Z's acceptance of Covid-19 information in digital media with a qualitative approach to reception analysis. Data were obtained through FGDs and in-depth interviews. Research findings show that Gen $Z$ prefers access to information that is fast-paced and practical; has a preference for news that is more relaxed, positive and informative; has adequate information literacy to identify hoaxes and perform fact checks; and has a reading position of negotiation and opposition with diverse behavior, but not hegemony-dominant. The results of this study contribute to the qualitative data of Gen-Z reception of Covid-19 information among the available quantitative data.
\end{abstract}

Keywords: Gen Z, reception, Covid-19 information, digital media

\section{INTRODUCTION}

The interaction of Generation $\mathrm{Z}$ or Gen $\mathrm{Z}$ with the media is an interesting topic to study. The paradigm of active audiences in this age group has different characteristics compared to other generations. Who is Gen Z? According to Bruce Horovitz, who introduced the term of generation $\mathrm{Z}$ for the first time, Gen $\mathrm{Z}$ is a generation with an age range of 17 to 24 years or born from 1995 to 2014 . The main characteristic of Gen $\mathrm{Z}$ according to Huntley is that they have enjoyed the wonders of technology after the birth of the internet in all their life activities (Purwani \& Kertamukti, 2020). This generation grows and develops along with the dynamics of the rapid advancement of digital technology. Therefore, they become very dependent on gadgets and activities in digital media in their daily life.
The existence of exposure to technology from an early age and the ease of obtaining information play a pivotal role in shaping Gen Z. Newspaper, radio, and news on television are conventional ways to obtain information. A very striking difference from generation $\mathrm{Z}$ to other generations is the use of cell phones. Based on Tirto.id's research on Gen $\mathrm{Z}$ in Java and Bali, $14.4 \%$ use television as the main source of information, $83.6 \%$ get information from the internet, and $1.7 \%$ read newspapers. Access to the internet is further divided into $35.2 \%$ accessing news from social media, $26.1 \%$ from browsers, $14.1 \%$ from messaging service applications, and $8.2 \%$ via Youtube or web streaming (Zuhra, 2017). The use of easy internet access via cell phones along with living in the era of globalization in Gen $\mathrm{Z}$ produces a generation that depends on the internet. The impact of the ease of 
accessing the internet makes it the main reference source in finding information (Firamadhina \& Krisnani, 2021).

Tirto.id's research on 1,201 respondents with an age range of 7-21 years in big cities in Indonesia such as Jakarta, Bandung, Surabaya, Yogyakarta, Tangerang, and Denpasar in mid-2017 (Tirto.id, 2020) shows that the media used by Gen $\mathrm{Z}$ to access news are social media $(35.2 \%)$, browser $(26.1 \%)$ and television $(14.4 \%)$ and their internet access averages 3 to 5 hours per day. Gen $\mathrm{Z}$ is more individual, more open-minded, and prefers to communicate with an internet connection (digital intuitive). The results of a survey conducted by researchers to recruit research informants showed that Gen $\mathrm{Z}$ chose digital media or the internet as the main source of information for reasons of ease and speed of access and the availability of unlimited information. This is in line with Tirto.id's findings regarding the reasons Gen $\mathrm{Z}$ choose their main information media, namely ease of access $(41.3 \%)$, large number of users $(23 \%)$, and complete information $(21.5 \%)$.

In fact, Gen $\mathrm{Z}$ is not only named the biological child of digital technology, but they are also experiencing a prolonged pandemic condition. This condition makes their space for movement limited and surfing activities in the digital space increase. One of the activities they do when surfing the internet during a pandemic is looking for information about Covid-19. Covid 19 information in cyber media based on data is the most sought-after information throughout 2020 on the Google search engine for the news category (Global, 2020). But keep in mind that not all information related to Covid-19 in digital media is true. It also contains fake news or hoaxes.

The spread of fake news and information about Covid-19 during the pandemic certainly causes panic for some people, especially those who do not have adequate media literacy skills (Supriadi et al., 2020). Meanwhile, media communication carried out by the government is still not effective because it gives too much confidence and there is no consistency (Ardiyanti, 2020).

The public selective behavior in choosing Covid-19 information in the mass media is ensuring that it is following needs, regulating the frequency of accessing COVID-19 information, and checking information from other sources (Yudhaswara \& Hidayat, 2021). A social media study in Indonesia found that social media culture can act as a teacher that is able to educate the public and stimulate the latest research related to COVID-19 (Sampurno et al., 2020).

As of mid-October 2020, according to the Minister of Communication and Information of the Republic of Indonesia, Johnny G. Plate, there were 1,197 findings of the COVID-19 hoax issue spread across several digital platforms as many as 2020 hoaxes with details; Facebook 1,497, Instagram 20, Twitter 482, and YouTube 21. Some of the hoaxes that have been taken down or blocked are 1,759, namely on Facebook are 1,300, Instagram are15, Twitter are 424, and YouTube are 20 (Putri, 2020). Based on these data, it can be seen that the COVID-19 hoaxes are widely spread on social media, not in mainstream media.

The rise of hoaxes related to Covid-19 on social media and the high level of consumption of social media as a source of information for Gen $\mathrm{Z}$ lead researchers to the question of how Gen $\mathrm{Z}$ accepts information about Covid-19 in digital media. Do they just accept all the information that is spread in digital media or do they make a selection by recognizing which is fake news and which is true information according to facts? How are they receiving the information circulating in digital media related to Covid-19? 
Then, how can the information they get regarding Covid-19 be reproduced in their daily lives?

The most dominant characteristics of Generation Z (Stillman, 2018)are; (1) Fig. Gen $\mathrm{Z}$ was born to see the world and all its technological advances. They live in a new world where rapid technological advances are removing the barrier between the physical and the digital. This amalgamation affects their daily life; (2) Hyper-Customization. Gen $\mathrm{Z}$ is always trying to adapt their identity and make customizations to be known to the world. Their ability to customize things gives rise to the expectation that their behavior and desires are familiar to understand; (3) Realistic. Gen Z has gone through a hard crisis from an early age that forms a pragmatic mindset in planning and preparing for the future; (4) FOMO or Fear of Missing Out. Gen Z includes people who are very afraid of missing out on information. They are always at the forefront of trends and competition; (5) Weconomist. Gen Z knows the world in new, practical and cost-effective ways; (6) Do it yourself: prefer to do a lot of things yourself in order to make things easier and faster. This could clash with the collective culture that Millennials previously struggled with; (7) Driven. Gen $\mathrm{Z}$ believes in winners and losers. Gen $Z$ is ready and active in competition because life is very digital. For previous generations, such as Generation Y, the source of information is from television, the second is from the source engine, and the last is social media. On the other hand, Gen $\mathrm{Z}$ gets information from social media, search engines, and finally television. Gen $\mathrm{Z}$ does not like reading newspapers, magazines, and watches television less because internet access is very easy.

These characteristics have an influence on the way Gen $Z$ receive and interpret the information they receive regarding Covid-19. As research has been done on the Millennial Generation's acceptance of advertising (Oktayusita et al., 2020) and assertive messages on blogs (Nair, 2020), culture also has an important role in the way Millenials read and respond to the information they receive in social media in their daily life. Other research on audience reception of media messages about cyberbullying also emphasizes that daily activities and social experiences can have an influence on the way audiences read media texts and respond to them (Haryanti \& Ratna Sari, 2018).

Some scholars argue that the categorization of generations into Gen $\mathrm{X}, \mathrm{Y}$, and $\mathrm{Z}$ should be reconsidered for the Indonesian context (Muhammad Faisal, 2020), this study uses Gen Z categorization to provide boundaries and focus on certain age ranges. A research on the lifestyles of youth Muslim shows that they try to get lessons about religion through recitations on virtual networks (Nisa et al., 2007).

In addition, another factor that is thought to influence Gen Z's acceptance of information related to Covid-19 in digital media is their ability to both technically and critically think in consuming information in digital media. This ability is known as digital literacy, especially in the context of information literacy. It is one of the things that should be owned by Gen $\mathrm{Z}$ as students during the Covid-19 pandemic until entering the new normal that forces them to interact a lot and do activities using digital technology. Digital literacy is the main capital for students to face the current condition (Kusumalestari, 2020).

Reception analysis was chosen as a theory to analyze the findings in this study because of its approach that emphasizes media consumption in the daily life of the audience. According to Narottama (2008), reception analysis is an analysis 
that emphasizes the views of the audience and how they produce something different from what is offered by the media. The audience's experience with media on a daily basis will depend on social location, age, culture, occupation, gender, and so on. Acceptance analysis finds the causes why audiences interpret things differently based on psychological and socio-cultural factors (Fauzi \& Fasta, 2020).

Referring to this theory, the code that is sent (encoded) and received(decoded) is not always equivalent or symmetrical. This difference is defined as the level of understanding and misunderstanding of the exchange of messages in the communication process, depending on the similarities or differences in reactions formed between the encoder and decoder. The position of the encoder and decoder can be expressed as the maker and recipient of the message (Storey, 2010).

According to Stuart Hall (Storey, 2010), audiences decode media messages through three possible positions: (1) Dominant hegemonic position, namely a situation where the media produces the message; the masses consume it. The audience reading coincides with the preferred reading. So in this position the audience will receive the full meaning as desired by the message maker. In other words, the message that has been created and delivered by the media, can really be well received by the audience; (2) Negotiated position, the audience will accept the dominant ideology and refuse to apply it to certain cases. As Stuart Hall says, the audience assimilates the leading ideology in general but opposes its application in specific cases. The audience will accept the ideology in general but will refuse to apply it if there is a difference with their culture. More specifically, the audience will reject a message that is made if it is not in accordance with their beliefs; (3) Oppositional position, the audience rejects the meaning of the message given by the media and replaces it with a meaning according to their thoughts on the content of the media message. In this case, the audience does not accept and even completely rejects the program created and delivered by the media.

Through the study of this theory by David Morley (1980), the theory of how audiences capture a text is proposed as stated by Stuart Hall in television discourse - encoding/decoding. Morley emphasizes the three processes of reading texts as positions that are not stagnant, but more flexible in their categorization. According to him, the dominant or preferred reading in which the audience shares the code of the text and accepts their opinion fully and understand the meaning of his choice as intended by the producer or can be called a hegemonic reading; negotiated reading in which the audience only shares part of the text code and mostly accepts the preferred meaning, but they have a tendency to change the meaning based on knowledge, values, culture, experience. This group can also argue for some representations that may not be accurate. Furthermore, the reading opposition is where the audience is aware of the chosen meaning but does not share the text code. They reject it to construct alternative meanings (Storey, 2010).

Several studies intersect with this research but do not examine qualitatively Gen Z's acceptance of information about Covid-19. Some of them are research on Gen Z's acceptance of political advertising (Oktayusita et al., 2020) and film (Fadlilah et al., 2020). Other studies related to audience receptions examine blog (Nair, 2020), film (Fathurizki, 2018), television program (Fauzi \& Fasta, 2020), and Youtube video (Haryanti \& Ratna Sari, 2018). The study of information on Covid 19 looked at the reflection of vulnerability to gender and races (Estrela et al., 2020), its relation to preventive 
behavior (Liu, 2020), and disinformation related to the issue of Covid 19 (Vériter et al., 2020)and for the European Union (EU.

This study seeks to answer questions about how Gen $\mathrm{Z}$ receive information related to Covid-19 in digital media, what is their reading position and how the messages they receive are implemented in their daily lives.

\section{METHODS}

This study uses a qualitative approach. The qualitative approach according to Bogdan and Taylor (1975: 5 ) is defined as a research procedure that produces descriptive data in the form of written or spoken words from people and observable behavior. Compared with the quantitative approach, the qualitative approach is directed at the individual background and the individual holistically (Moleong, 2014).

The method used is reception analysis derived from the encodingdecoding approach proposed by Stuart Hall. Using this analytical tool, the researcher tries to reveal how the audience actively receives messages and the relationship between producers' and consumers' perceptions of the text. The meaning of the message depends on the background of the audience and their experience (Haryanti \& Ratna Sari, 2018). The encoding and decoding process is carried out by the media and the audience. Encoding is the process of making a message according to a certain code, while decoding is the process of using a code to interpret a message. In the process, the audience plays an active role in interpreting the messages they receive, which may not be in accordance with the meaning contained in the message itself (Fathurizki, 2018).

The primary data collection techniques used in this study were Focus Group Discussion (FGD) and in-depth interviews. The informants in this study were 12 students from several cities, namely Jakarta, Bandung, Pekalongan, Sorong, and Tanjungpinang. TABLE 1 shows students who became informants in this study.

The selection of 12 students as informants in this study was carried out first through the selection of informants by distributing online questionnaires

TABLE 1. Research Subject

\begin{tabular}{|c|c|c|c|}
\hline No. & Name & Domicile & Campus \\
\hline 1 & Jamalludin & Anambas, Kepulauan Riau & $\begin{array}{l}\text { Universitas Islam Negeri Sul- } \\
\text { tan Syarif Kasim Riau }\end{array}$ \\
\hline 2 & Ani Indriani Agustini & Palopo, Sulawesi Selatan & IAIN Palopo \\
\hline 3 & $\begin{array}{l}\text { Andi Aulia Nabilah } \\
\text { Anshari }\end{array}$ & Depok, Jawa Barat & $\begin{array}{l}\text { Politeknik Negeri Media } \\
\text { Kreatif Jakarta }\end{array}$ \\
\hline 4 & Ezza Arianty & Sorong, Papua Barat & Universitas Negeri Makassar \\
\hline 5 & Faisal Guntara & Bandung Barat, Jawa Barat & Universitas Islam Nusantara \\
\hline 6 & Hashim Thaci & Medan (sumatera utara) & Telkom University \\
\hline 7 & M Mucharom Syifa & Pekalongan, Jawa Tengah & IAIN Pekalongan \\
\hline 8 & Dicki & DKI Jakarta & Telkom University \\
\hline 9 & Annisa O.D & Bandung & Unisba \\
\hline 10 & Farhan A & Bandung & Telkom University \\
\hline 11 & Selvira Meiliza & Muara Bungo & STKIP Muhammadiyah MB \\
\hline 12 & Alam Syarizal & $\begin{array}{l}\text { Tanjungpinang Provinsi Kepu- } \\
\text { lauan Riau }\end{array}$ & UIN SUSKA Riau \\
\hline
\end{tabular}


using google forms. The distribution of the questionnaire was carried out from January 18 to February 11, 2021. A total of 207 respondents were collected to fill out the questionnaire. The results of the filled out questionnaire were then taken into consideration by researchers to select informants in this study using purposive sampling technique. The diversity of the data and the demographic background of the respondents are elements that are considered in the selection of informants.

\section{RESULTS AND DISCUSSION}

Gen $\mathrm{Z}$ as a generation born and raised by digital technology is often assumed to be the generation that is most familiar with digital technology and information. Their presence in the digital world occupies the largest portion when compared to other generations before and after them. The findings in this study provide a qualitative picture, how they 'chew' the information they get in digital media related to Covid-19 and how the reading position and the way they respond to and reprocess the information they get into their daily lives.

\section{Information Access}

The first interesting finding on the informants of this study is related to access to information. Students who became informants in this study belonged to Generation Z, which had different characteristics compared to previous generations. They were born and raised together with the rapid development of digital technology. Their ability to receive and understand information is automatically influenced by the presence of digital media that surrounds them.

The informants in this study showed the same characteristics as the general description of Gen Z, but the data from this study explored in more detail the reasons they chose certain media in seeking information. According to their characteristics, digital media is the main medium for them to access information. Another media option is television. Printed newspapers, magazines, tabloids, and radio are no longer an option for informants. The reason is that the media is difficult to access, especially print media. For radio, they claim to be more familiar with streaming radio or an application such as Spotify. It's not only for getting information, but also for listening to music.

Even though they use digital media or online media as a source of information, they turn out to be picky when it comes to media they think can be trusted. According to them, the news portals that can be trusted are Tempo.id, Kompas.com, and Tirto.id. The reasons are on the grounds that Tempo tends to be outspoken in its reporting, as well as Kompas. Another reason is that both media are considered to have big names, so they can be trusted. Meanwhile, for Tirto.id, which is a news portal that tends to be new, the reason the informants choose this media is the format that uses infographics and the reporting method which is considered independent and tends to be critical.

This is closely related to the many studies on Gen Z which show that they are highly skilled at accessing information. The openness given by new media makes them have unlimited access to information. This condition can bring benefits on the one hand but can also be detrimental. The informants felt that too much information about Covid-19 hit them, causing anxiety, fear and other negative emotions. Some people have responded by limiting access to information, especially those related to Covid-19. Frankly, they realized to be more selective in choosing news sources as the following statement :

"Depending on ourselves, for example, we can access the official website or news about Covid-19. 
(It) can be used to verify, reinforce each other or check recheck." (Farhan, informant)

"Must be good at filtering the news, if there is news that makes you restless and confusing, just ignore it. Focus more on prevention for yourself." (Ezza, informant)

"Let's not swallow it whole, see if the data is valid and check it first. Because some are hoaxes, some are not." (Annisa, informant)

\section{Media Preferences}

In addition to the news portal in the format of its own page, the informants in this study also use social media as a source that they think can be relied upon in providing as much information as possible. The most widely used social media are Twitter and Instagram. For Twitter, the power of trending topics from this social media platform turns out to be the main reason that makes it a source of information. Gen $\mathrm{Z}$ likes things that are fast and uncomplicated, so they prefer to use a fast way to find out what issues are being discussed. This need is facilitated by Twitter. As for Instagram, although it is included in the social media category, it turns out that informants access news portal accounts as sources of information, such as Tirto.id, Kompas, Tempo, CNBC, $\mathrm{CNN}$, and FOX Report accounts.

In practice, online news portals also have official social media accounts, such as Instagram and Twitter, some have even started using the TikTok platform. That way, when accessing social media, it could mean that they are accessing news portals but through their social media accounts. Sometimes they don't access certain mainstream media accounts for information. There are times when they exchange and seek information through individual or institutional social media accounts. The comment column on social media accounts is one source of information that they find interesting even though they can't just be trusted. According to one informant, looking for information on social media is more interesting, people are more expressive based on data, the information is wider because it depends on their perception, so it is more actual.

News aggregators such as those provided by LINE Today, Google, Yahoo, Bing, or other search engines are work based on artificial intelligence. Algorithms that are read by artificial intelligence will approach the audience personally, so that what appears on a person's screen is what he wants to see. According to informants, the existence of this news aggregator greatly saves time and effort in updating information. In a matter of minutes, they can find out what news is being talked about right now or what is going viral on social media. News aggregators are another option besides Twitter to update information. They have similar reasons as below:

"LINE Today is very helpful to spread information instead of having to look it up yourself. News aggregator has surpassed television." (Dicki, informant)

"On LINE Today, the news is faster than other media, it immediately appears on the homepage, so you can get the actual news quickly." (Annisa, informant)

Gen Z's choice of media as informants in this study tended to vary, as well as the choice of the type of information they absorbed. Then what about information related to Covid-19? They choose news aggregators and social media to get the highlight on the information they need. Online news that is short and not detailed is their reference to find out the latest information about Covid-19. Not infrequently they are also hit by click-bait, but they take it easy, not feeling too disappointed with some news 
that is sometimes inappropriate. Gen Z's more easy going character is one of the factors that influence the way they respond to this. The characteristic of Gen $\mathrm{Z}$ who always wants to be connected with information makes them more aware of what topics are trending.

The choice of visual appearance is also an important consideration for them. Graphics, images and other visualizations provide instant information without reading the sentences in detail one by one. This is characteristic of Gen $\mathrm{Z}$ even though they don't want to be called 'lazy reading'. According to them, "If something is easier, so why do we make it difficult?"

\section{Information Literacy}

The ability of Gen $\mathrm{Z}$ to understand and access information as well as to sort out what is true and not, qualitatively is quite diverse. Gen $\mathrm{Z}$ information literacy consists of the ability to recognize the types of Covid-19 hoaxes and perform fact checks. Findings related to information literacy skills that ranged from the ability to recognize hoaxes to doing fact checks and making fact-checking articles on Gen $\mathrm{Z}$ informants were quite varied.

The term hoax, of course, is familiar to their ears as the equivalent of fake news or fake news. Informants who come from various disciplines in general do not understand the difference between misinformation and disinformation even though they can recognize which information they think is not true. In the fact-checking category, several informants have conducted inspections in simple ways, such as tracing the source of the information and checking with reference to digital mainstream media or television to determine whether a news item is true or just a hoax.

Their attitude towards the Covid-19 hoax can also be said to be quite interesting because even though they can recognize hoaxes and understand the bad effects of hoaxes, they decide to remain silent when other people spread hoaxes in chat groups or on social media. One thing they never do is participate in spreading hoaxes. According to them, it was enough to stop the spread of hoaxes. In addition to checking and rechecking, another thing they do when they encounter hoaxes is to ask other people who they think understand hoaxes.

This research finding answers questions about Gen Z's attitude towards Covid-19 hoaxes. They did not verify the circulating hoax even though they realize that it is wrong and must be stopped. Disdain for older family members or people with more power is a major reason for their silence. The culture of courtesy makes Gen $\mathrm{Z}$ reluctant to disagree with other older generations regarding the Covid-19 hoax.

\section{Reading Position}

Referring to the theory of reception or acceptance according to Stuart Hall, Gen $\mathrm{Z}$ also has a different reading position, namely hegemony-dominance, negotiation, and opposition. Informants indicate reading positions that vary between the three reading positions. That is, regarding information about Covid-19, there are those who receives and interprets the information contained in digital media by conducting negotiations, sorting out information that they think is in accordance with their values, experiences and other references. This negotiation position was shown by many informants. Meanwhile, for the opposition reading position, it is shown mainly for information that is felt to disturb them emotionally, for example, makes them restless, afraid, and worried. In fact, the informant with this reading position decided to temporarily close access to information related to Covid-19.

Among the informant of Gen Z in this study, the hegemonic-dominant 
reading position was not found. Although there is a tendency towards hegemonistic the informants still negotiate the meaning of the information they receive even though the level is only small. This can be seen in informants who tend to be apathetic to the amount of misinformation circulating in cyberspace related to Covid-19.

Talking about generation $\mathrm{Z}$ will not be separated from the discussion about digital technology. Why? Born at a time when digital technology is developing rapidly, Gen $\mathrm{Z}$ grows into people who are familiar with digital technology, is instantaneous, lack ambition, does not like to be 'complicated'. Unlike the previous generations, namely Gen $\mathrm{X}$ and Gen Y (millennials), this generation has an extraordinary closeness to digital information technology. They are very familiar with digital media and make this media their main reference for getting information.

The rise of hoaxes related to Covid-19 in digital media made the generations before them feel worried. But in reality, they have their own abilities and mechanisms when receiving information related to Covid-19 in digital media which is influenced by their characteristics as a generation that grew up with the internet and all its complexities. As the majority inhabitants of the digital world, they have great power to build a healthy digital information ecosystem related to Covid-19 and this pandemic. The war against the infodemic will continue as long as the Covid-19 hoax continues to spread rapidly and the role of Gen $\mathrm{Z}$ is very much needed. The diversity of the respondent's demographic background is one of the elements that influenced the reading position, media preference, and information literacy of informants.

\section{CONCLUSION}

Based on the research findings and discussion on the theory used in this study, it can be concluded that Gen Z's acceptance of information related to Covid-19 can be explained in the context of information literacy and reading position.

In the context of information literacy, the ability to recognize hoaxes is a basic skill that has been possessed, but the attitude towards hoaxes is not the same for every informant. There are those who verify by asking questions or checking sources and comparing with other media, but there are also those who do not care. Even though they know how to check facts in a simple way, they tend to be silent and don't help straighten out when there are hoaxes circulating regarding Covid-19 in their digital environment.

In the context of the reading position, hegemonic-dominant is not indicated. The dominant reading position is negotiation. Informants choose which information is in accordance with their frame of reference and field of experience and interpret information related to Covid-19 according to the values they consider correct. Another indicated position is the reading position, the opposition in which the informant rejects information that hits him by closing access to information related to Covid-19.

The results of this study expose opportunities for further research related to Gen Z's acceptance of information related to Covid-19 and provide novelty in terms of references and new findings of qualitative data about Gen $\mathrm{Z}$ and the Covid-19 infodemic among similar studies.

\section{ACKNOWLEDGMENT}

Thank you to LPPM Unisba for funding this research with the grant contract number 099/B.04/LPPM/ $\mathrm{X} 11 / 2020$

\section{REFERENCE}


Ardiyanti, H. (2020). Komunikasi Media Yang Efektif Pada Pandemi Covid-19. INFO Singkat: KAJIAN SINGKAT TERHADAP ISU AKTUAL DAN STRATEGIS DPR RI, Vol. XII(7), 2530.

Estrela, F. M., E Soares, C. F. S., da Cruz, M. A., da Silva, A. F., Santos, J. R. L., Moreira, T. M. de O., Lima, A. B., \& Silva, M. G. (2020). Covid-19 pandemic: Reflecting vulnerabilities in the light of gender, race and class. Ciencia e Saude Coletiva, 25(9), 34313436. https://doi.org/10.1590/141381232020259.14052020

Fadlilah, I., Permadi, W., Leony, S. M., Studi Ilmu Komunikasi UPN, P., \& Timur, J. (2020). Mulan 2020: Studi Analisis Resepsi Generasi Z Terhadap Karakter Pemimpin Perempuan. 60-72.

Fathurizki, A. (2018). PORNOGRAFI DALAM FILM : ANALISIS RESEPSI FILM “ MEN , WOMEN \& CHILDREN " Film Men , Women FILM “ MEN, WOMEN \& CHILDREN " tidak masuk ke Indonesia . Penonton di Indonesia hanya bisa menikmati film ini dengan menonton secara online di website streaming fil. ProTVF, 2(44), 19-35.

Fauzi, E. P., \& Fasta, F. (2020). Modern Muslimah in Media : a Study of Reception Analysis in "Saliha " Program on Net Tv. Aspiration, 1(November), 135-162.

Firamadhina, F. I. R., \& Krisnani, H. (2021). PERILAKU GENERASI $Z$ TERHADAP PENGGUNAAN MEDIA SOSIAL TIKTOK: TikTok Sebagai Media Edukasi dan Aktivisme. Share: Social Work Journal, 10(2), 199. https://doi.org/10.24198/share. v10i2.31443

Global. (2020). Year in Search. https:// trends.google.com/trends/yis/2020/ GLOBAL/

Haryanti, A., \& Ratna Sari, S. D. S. (2018). Analysis of Audience Reception on Youtube Towards Anti Cyberbullying Video Campaign in the Cyber Bully By Cameoproject. Social Economics and Ecology International Journal (SEEIJ), 2(1), 57-63. https://doi. org/10.31397/seeij.v2i1.20

Kusumalestari, R. R. (2020). Literasi Digital dan Infodemik: Sebuah Upaya Menghadapi Banjir Informasi pada Masa Pandemi COVID-19. In Japelidi.

Liu, P. L. (2020). COVID-19 Information Seeking on Digital Media and Preventive Behaviors: The Mediation Role of Worry. Cyberpsychology, Behavior, and Social Networking, 23(10), 677-682. https://doi. org/10.1089/cyber.2020.0250

Moleong, L. J. (2014). Metode Penelitian Kualitatif. Remaja Rosdakarya.

Muhammad Faisal. (2020). Generasi Kembai ke Akar. KOMPAS.

Nair, T. (2020). Durban Millennials , Reception Analysis of GreenPeaceAfrica 's 2020 Blog Post about Single Use Plastic during Covid-19: A Descriptive Qualitative Online Questionnaire . Tenielle Nair SUMMATIVE RESEARCH REPORT RESE8419 THE IIE BACHELOR OF ARTS HONOURS IN.

Nisa, A., Reciana, K., \& K, B. (2007). Youth Lifestyle in A Moslem Magazine: A Reception Analysis on "Muslimah" Readers. Mediator: Jurnal Komunikasi, 8(1), 113-124. https:// doi.org/10.29313/mediator.v8i1.1231

Oktayusita, S. H., Suparno, B. A., \& Rochayanti, C. (2020). Reception Analysis of Millennials Generation to Ads in Social Media. Jurnal Ilmu Komunikasi, 17(2), 125. https://doi. org/10.31315/jik.v17i2.3696

Purwani, D. A., \& Kertamukti, R. (2020). Memahami Generasi Z Melalui Etnografi Virtual. ResearchGate, January, 65-76. https://www.researchgate.net/ publication/338764624 Memahami Generasi_Z_Melalui_Etnografi_ Virtual

Putri, Z. (2020). Kominfo Temukan 1.197 Hoax Terkait Isu Corona di Medsos. Kominfo Temukan 1.197 Hoax Terkait Isu Corona di Medsos

Sampurno, M. B. T., Kusumandyoko, T. C., \& Islam, M. A. (2020). Budaya Media Sosial, Edukasi Masyarakat, dan Pandemi COVID-19. SALAM: Jurnal 
Kusumalestari, dkk. Gen Z's Reception of Covid-19 Information on...

Sosial Dan Budaya Syar-I, 7(5). https:// doi.org/10.15408/sjsbs.v7i5.15210

Stillman, D. S. J. (2018). Generasi Z : memahami karakter generasi baru yang akan mengubah dunia kerja. In Monograf (2nd ed.). Gramedia Pustaka Utama.

Storey, J. (2010). Cultural Studies dan kajian Budaya Pop. Jalasutra.

Supriadi, Y., Drajat, M. S., Saleh, N. L., R., A. S., \& Huda, A. S. N. (2020). The Role of the West Java Indonesian Broadcasting Commission (KPID) in Preventing Citizen Panic Related to News and Information Regarding Covid-19. Mediator: Jurnal Komunikasi, 13(2), 167-177. https://doi.org/10.29313/ mediator.v13i2.6573

Tirto.id. (2020). Masa Depan di Tangan
Generasi Z.

Vériter, S. L., Bjola, C., \& Koops, J.A. (2020). Tackling covid-19 disinformation: Internal and external challenges for the European union. The Hague Journal of Diplomacy, 15(4), 569-582. https:// doi.org/10.1163/1871191X-BJA10046

Yudhaswara, R. K., \& Hidayat, D. (2021). Deskripsi Pengalaman Perilaku Selektif Memilih Informasi Di Masa Pandemi Covid-19 Pada Media Massa Televisi Description of Selective Behavioral Experience of Choosing Covid-19Information in Mass Media Television.

Zuhra, W. U. N. (2017). Kelahiran Generasi Z, Kematian Media Cetak. https:// tirto.id/kelahiran-generasi-z-kematianmedia-cetak-ctLa 